\title{
Field notes on the breeding biology of the Dotterel Charadrius morinellus in arctic Norway
}

\author{
Fältnoteringar om häckningsbiologin hos fjällpipare Charadrius morinellus $i$ \\ arktiska Norge
}

LUTZ LÜCKER, SIEGFRIED KRAATZ †, BÄRBEL KRAATZ

\begin{abstract}
From 2002 to 2010 twenty-four Dotterel nests were observed on Varangerfjell plateaus near Batsfjord. Females definitely took part in incubation in 18 cases. However, shared incubation could not be ruled out for the remaining 6 nests. One female defended the chicks against her own partner before they left the nest. Another lone female was seen leading 3 chicks for 5 days in a very small section of the study area, to our knowledge the only case of a female with chicks outside the nest ever recorded.

Several nests were found less than $100 \mathrm{~m}$ apart. One bird laid eggs in the same nest in 2 consecutive years. These findings complement previously published observations and hypotheses.

Lutz Lücker, CH-1213 Petit-Lancy/Geneva, 5, Fort-Ecluse,email: lutz6lucker@yahoo.de Bärbel Kraatz, D-17489 Greifswald, Hoher Weg $9 a$
\end{abstract}

Received 15 May 2011, Accepted 1 August 2011, Editor: S. Svensson

\section{Introduction}

Dotterel females have been known to be polyandrous for a long time (Berg 1917, Géroudet 1982, Cramp \& Simmons 1983, Owens et al. 1995), deserting their males after egg-laying in order to lay more clutches (normally three eggs) with other males. Females may maintain a loose relationship with the incubating male, especially to warn the male of potential dangers. Otherwise, very little is known about the role of females; only a few authors (Géroudet 1982, Cramp \& Simmons 1983, Nethersole-Thompson 1973) mention that some females may occasionally take part in incubation, the only precise proportions recorded so far being 9 out of 27 nests on Hardangervidda in southern Norway (Kalas \& Byrkjedal 1984) and 4 out of 32 nests on Värriötunturi in Finland (Pulliainen \& Saari 1997). However, there are no records of females attending chicks after leaving the nest, or double-clutching (male and female incubating two clutches, which occurs with Mountain Plover Charadrius montanus (Cramp \& Simmons 1983) and certain Calidris species (Maynard Smith 1978).

Site fidelity is believed to be weak (Cramp \& Simmons 1983, Hable 1975), but each year we systematically tried to find the location of old nests in order to see how faithful Dotterel are to former nesting territories.

Population density does not exceed 17 nests/100 hectares ( 6 nests and 4 broods on 58 ha) on mountain tops with restricted suitable habitat surface (Pulliainen, Saari \& Tunkkari 1992, NethersoleThompson 1973, Piersma \& Wiersma 1996, Cramp \& Simmons 1983). Dispersal of chicks after hatching is believed to be fast and over large distances (Géroudet 1982). Generally, Dotterel are thought to be extremely confiding. Some authors (Cramp \& Simmons 1983, Géroudet 1982, Hable 1975) give the impression that sexing of adult birds is extremely difficult, even from a short distance.

The Dotterel seems to be common all over the Varanger peninsula on uninhabited plateaus and slopes which are not too steep, between 320 and $420 \mathrm{~m}$. above sea level. More than $1800 \mathrm{~km}^{2}$ of the area is now a national park with strict protection of this species. It is one of the largest virtually treeless areas in Fennoscandia, home to endangered species like Gyrfalcon Falco rusticolus and Arctic Fox Alopex lagopus, as well as an important moulting site for Bean Geese Anser fabalis (Aarvak \& Øien 2009). Here the Dotterel reaches the northernmost fringe of its distribution. Unfortunately, even these seemingly virgin habitats might be threatened by 
indirect effects of climate change. Lemming peaks have become scarce and irregular (Kausrud et al. 2008), and some of their traditional predators like skuas have to forage on wader or grouse chicks and eggs. Red foxes Vulpes vulpes hunt at higher altitudes, endangering both arctic foxes and breeding birds in these fell habitats.

One of our research motivations was the fact that the number of Dotterel have decreased dramatically since the 1950-1970s (Saari 1995) and figure as "near threatened" on the Finnish Red List (Rassi et al. 2010). In spite of its decline the Dotterel is still a species of least concern for IUCN (Birdlife International 2009) since the world-wide population is estimated to be somewhere between 49,000 and 210,000 birds (Wetlands International 2002). Nevertheless our first priority was conservation and we always tried to disturb the birds as little as possible.

In the Varanger type of habitat Dotterel nests are to be found in the vicinity of nests or territories of Ptarmigan Lagopus mutus, Ringed Plover Charadrius hiaticula, Golden Plover Pluvialis apricaria, Purple Sandpiper Calidris maritima, Temminck's Stint Calidris temminckii, Turnstone Arenaria interpres, Shorelark Eremophila alpestris, Northern Wheatear Oenanthe oenanthe, Lapland Bunting Calcarius lapponicus and Snow Bunting Plectrophenax nivalis. Potential predators of eggs and chicks, such as Arctic Skua Stercorarius parasiticus and Long-tailed Skua Stercorarius longicaudus, may breed within $400 \mathrm{~m}$ of the nearest Dotterel nest.

Other occasional or rare threats include Gyrfalcon, very rare, Merlin Falco columbarius and Rough-legged Buzzard Buteo lagopus, both rare above the tree-line, Golden Eagle Aquila chrysaëtos, rare, and Snowy Owl Nyctea scandiaca, only recorded in July 2003. Raven Corvus corax and Herring Gull Larus argentatus are no threat to adult Dotterel. We observed Red Fox three times above 320 m. a.s.1., Arctic Fox was recorded only once, and Stoat Mustela erminea were not seen annually; they are rare except during Lemming peaks (which we only noticed in 2008 before mid-June). Once we found fox sp. droppings in a nest that had been used a year earlier. On the other hand, Reindeer Rangifer tarandus can be quite numerous in July (a trampled Dotterel nest was found in 2008).

The main questions we wanted to answer in our study were:

- How common is female participation in incubation in this area?

- How long do females participate in incubation?
Our observations led us to four more issues:

- Are females also able to take care of chicks during and after hatching?

- Could double-clutching be proved?

- Do all Dotterel have the same confiding attitude near their nests?

- Was there any evidence of site fidelity between years?

\section{Material and methods}

\section{Study areas}

Our study areas were less than $1800 \mathrm{~m}$ from road 891 which leads from Gednje T-junction to Batsfjord at $70^{\circ} 32$ 'N / $29^{\circ} 22^{\prime} \mathrm{E}$. Nests were found between 320 and $420 \mathrm{~m}$. a.s.l. in only inch-high vegetation of Salix glandulosa, Salix herbacea, Loiseleuria procumbens, Silene acaulis, Arctostaphylos uva-ursi, Cladonia rangiferina and Vaccinium myrtillus. Frequently eggs are laid next to a house brick-sized stone, covered with Rhizocarpon geographicum and other lichens. The approximate size of the three areas where nests were found is 35 $+75+25(=135)$ hectares, to which we may add another 60 ha of identical habitat that was systematically searched but with no success.

\section{Data collecting}

When we first met in early July 2002, Siegfried and Bärbel Kraatz had started observing their second Dotterel clutch where male and female were sharing incubation. We found four more such pairs in 2004 and Siegfried, in spite of his declining health, found two more in 2005. Shortly before his premature death he wrote his second article on incubation-sharing female Dotterel (Kraatz \& Kraatz 2004, 2006). From 2007 to July 2010 Bärbel Kraatz and I returned to our study areas each year to extend our knowledge of this practice. The length of our 10 stays went from 6 to 43 days (mean: 26,5 days; see Table 1).

Throughout the study period sampling was difficult and irregular. In six years we only arrived after the 27 June when most clutches had been laid. In seven years we had to leave by 25 July, before the last clutches had hatched. Thus, we could not check if females continued or resumed their participation until or after hatching. In 2004 and 2005 Siegfried's health problems did not allow him to study the birds regularly. Weather conditions made field work often difficult, as snow storms or showers occurred even in June or July, as well as thick coastal fog and $25 \mathrm{~m} / \mathrm{sec}$ gales, which made stand- 
Table 1. Observation periods, and data on participation by the different sexes in chick attendance. Observationsperioder samt data om deltagande i omvårdnaden av ungarna för de olika könen.

\begin{tabular}{|c|c|c|c|c|c|}
\hline \multirow[t]{2}{*}{ Year } & $\begin{array}{l}\text { Observation period } \\
\text { (no. of days) }\end{array}$ & $\begin{array}{l}\text { Nests with female } \\
\text { participation } \\
\text { (no. of days with } \\
\text { female on nest) }\end{array}$ & $\begin{array}{l}\text { Nests with no } \\
\text { proved female } \\
\text { participation }\end{array}$ & $\begin{array}{l}\text { No. of cases } \\
\text { with chicks } \\
\text { attended by } \\
\text { male from } \\
\text { unknown nest }\end{array}$ & $\begin{array}{l}\text { No. of cases } \\
\text { with chicks } \\
\text { attended by } \\
\text { female from } \\
\text { unknown nest }\end{array}$ \\
\hline & $\begin{array}{l}\text { Observationsperiod } \\
\text { (antal dagar) }\end{array}$ & $\begin{array}{l}\text { Bon med hona } \\
\text { deltagande (antal } \\
\text { dagar med honan } \\
\text { på boet) }\end{array}$ & $\begin{array}{l}\text { Bon utan } \\
\text { bevisat } \\
\text { deltagande av } \\
\text { honan }\end{array}$ & $\begin{array}{l}\text { Antal fall med } \\
\text { ungar vårdade } \\
\text { av hane från } \\
\text { okänt bo }\end{array}$ & $\begin{array}{l}\text { Antal fall med } \\
\text { ungar vårdade } \\
\text { av hona från } \\
\text { okänt bo }\end{array}$ \\
\hline 2001 & 13 Jun-8 Jul (26) & $1(10)$ & & & \\
\hline 2002 & 6 Jun-9 Jul (34) & $1(13)$ & & & \\
\hline 2003 & 7-11 and 29 Jul (6) & & 1 & 1 & \\
\hline 2004 & 27 May-8 Jul (43) & $4(1,6,8,8)$ & 1 & & \\
\hline 2005 & 28 Jun-8 Jul (11) & $1(8)$ & 1 & & \\
\hline 2006 & 5-13 Jul (9) & & & & \\
\hline 2007 & 28 Jun-22 Jul (25) & $1(1)$ & 2 & & \\
\hline 2008 & 18 Jun-22Jul (35) & $3(6,9,16)$ & & 1 & \\
\hline 2009 & 26 Jun-25 Jul (30) & $3(3,3,11)$ & 1 & 1 & 1 \\
\hline$\underline{2010}$ & 28 Jun-31 Jul (34) & $4(1,1,3,8)$ & & 3 & \\
\hline Total & 265 days & 18 (116 days) & 6 & 6 & 1 \\
\hline Mean & 26.5 days & 6.42 days & & & \\
\hline Range & 6-43 days & $1-16$ days & $1-2$ & $1-3$ & \\
\hline
\end{tabular}

ardized sampling just impossible. Only when the weather was dry, the wind moderate or light, and temperatures above $5^{\circ} \mathrm{C}$, we tried to identify the sex of the birds on each nest, if possible twice a day, using $8-10 \times$ binoculars or $20-60 \times$ telescopes from a safe distance. Since Siegfried had already noticed in 2002 that females could be found on a nest at any time, we did not even try to check the nests at the same hour every day; we depended too much on the extremely variable weather. In order to avoid disturbance during periods of poor weather, we frequently had to stop monitoring nests for several consecutive days.

Except during hatching periods L.L. never observed the same nest for more than 60 minutes. But in 2002 S. \& B.K. found a clutch $125 \mathrm{~m}$ from their camping car. They stayed in the vicinity of the nest for up to 22 consecutive hours and were even able to check it every 15 minutes and every night when visibility was good enough. We never used hides but stayed at a distance of at least $4 \mathrm{~m}$ so that the incubating birds were not too much stressed. At the end of each period of observation we left a few mealworms in the hope that the birds might associate our coming with food and of no threat. After the first visits this often seemed to work; more than $50 \%$ of the birds remained in an upright position or almost fell asleep in our presence once they had got used to it. We never tried to touch the birds like Berg (1917) or Arendt \& Schweiger (2007).

We did not attempt to find more than 4 nests each year, preferring to concentrate on a small number instead of losing a lot of time looking for more. On 3 occasions we observed feeding males in July for $2 \frac{1}{2}$ to $3 \frac{1}{2}$ hours before they finally flew away, quickly disappearing behind some low hump so that we could not find their clutch. Indeed, incubation-sharing means that the relieved bird can go and feed far away from its nest for prolonged periods. This may be an advantage for breeding birds in arctic weather conditions but it makes nestsearching more difficult.

Sexing of incubating birds appeared straightforward in good viewing conditions from mid- June to late July. It never took us long to tell which of the two birds was incubating. In all cases we found that breeding females in this area have a set of distinctive diagnostic features. Their extremely white cheeks have very few or no dark streaks, and the rear part of the crown is blackish with very few or no light brown streaks (Figure 1). The female's dark belly patch is much larger than that of the male. Hable (1975) is the only one to say that it is the patch of the male that is largest, and this is 

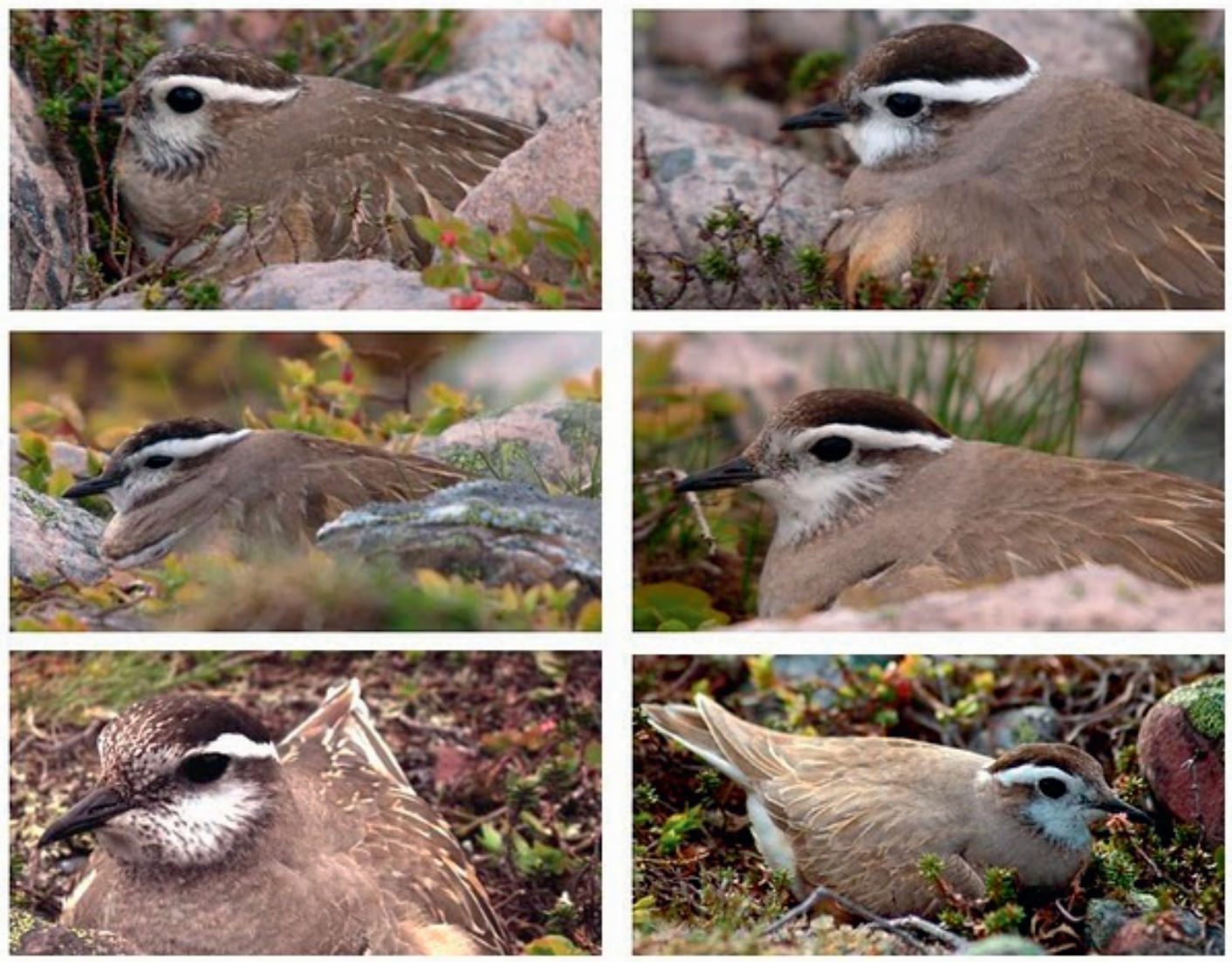

Figure 1. Male (left) and female (right) Dotterel from three different pairs.

Hanen (vänster) och honan (höger) från tre olika par av fjällpipare.

wrong. The majority of males have a number of light feathers showing well in this dark patch, perhaps a sign of early contour feather moult. In general they look less colourful than females. When both birds were standing close to each other the difference in size as well as their positions during copulation confirmed the the sexing characters that we used. In August, however, the sex differences tend to disappear rapidly, which makes it impossible to sex migrating adults.

\section{Results}

All nests were found either on dry, flat terraces and plateaus or on slightly inclined slopes, never on a hilltop or a summit ridge. Only one nest was virtually surrounded by small rivulets coming from a huge melting snowdrift. Hatching dates $(n=8)$ went from 4 to 27 July; replacement clutches may have been laid as late as 9 July so that a few chicks may have hatched in early August. From June 2002 to July 2010 we found 24 nests, $18(=75 \%)$ of which were definitely incubated by two different birds after completion of egg-laying on 1 to 16 consecutive days, the average being 6.42 days (Table 1). The remaining 6 nests (with males only) could never be observed long enough to completely rule out female participation. Either those nests were found too late, abandoned, robbed or destroyed, or we had to leave the area before hatching. (We did not take into account a 25 th nest which was robbed within less than 24 hours.) As for the 18 females, 7 were found sharing incubation only during the first week, 4 only during the last week; we did not find a consistent pattern. In two cases the female was only seen on the nest one or two days before hatching. One nest in 2004 may have been a replacement clutch of a pair whose nest had been robbed. The 
photographs we had made of the parents at both nests looked very much alike but the birds were not colour-banded. We never found more than 4 nests per season; in 4 years we only found 1 nest (Table 1). Moreover, we witnessed 8 hatchings in four years; only on two occasions the female was present.

In July 2002, S. \& B.K. found a nest near their camping car so that they could virtually monitor it round the clock. They found that the female stayed on the nest between $60 \mathrm{~min}$. and 26 consecutive hours, assuming approximately $55 \%$ of incubation until hatching (Kraatz \& Kraatz 2004). S.K. was probably the first person to publish a photograph of a female incubating chicks during hatching (Figure 2 ). When the second chick had hatched, the female disappeared and the male took over.

Contrary to the common belief that Dotterel are very confiding, the incubating birds on 3 different nests were so shy that they left the nest when we were between 80 and $300 \mathrm{~m}$ away, rarely or never allowing us to identify their sex. On 30 June 2009 we observed from a distance of about $100 \mathrm{~m}$ a male Dotterel going back to its nest. When we approached the bird ran away and disappeared. Over the next 15 days we only once managed to see an unidentified bird on this clutch; each time we arrived it left the nest so early that we had no chance to spot and/or sex it. Twice, its eggs seemed

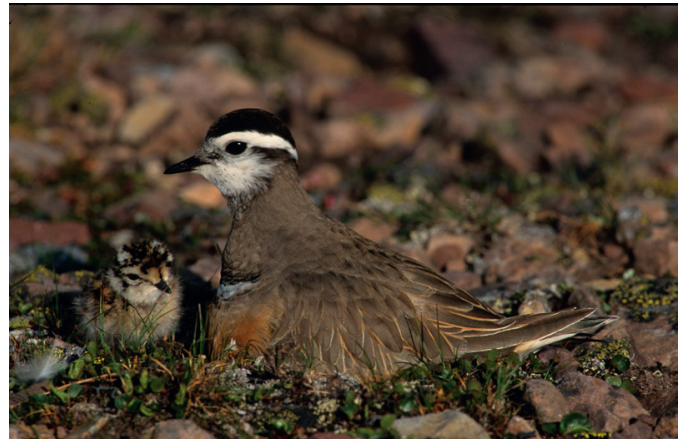

Figure 2. First case ever recorded of a female Dotterel that is sitting on the clutch during hatching of the chicks.

Första observationen någonsin av en fjällpiparhona som ruvar kullen under kläckningen.

to be so cold that we started to believe that the nest had been abandoned. However, on 16 July we discovered a confiding female incubating two chicks and an egg in this nest! When the third chick had hatched, the male bird arrived and attempted to take over, trying to brood the firstborn chick which was looking for food about $4 \mathrm{~m}$. from the nest. However, he was violently driven away by the female (Figure 3 and Appendix). These skirmishes with leap-frogging and shrill calls were repeated 6

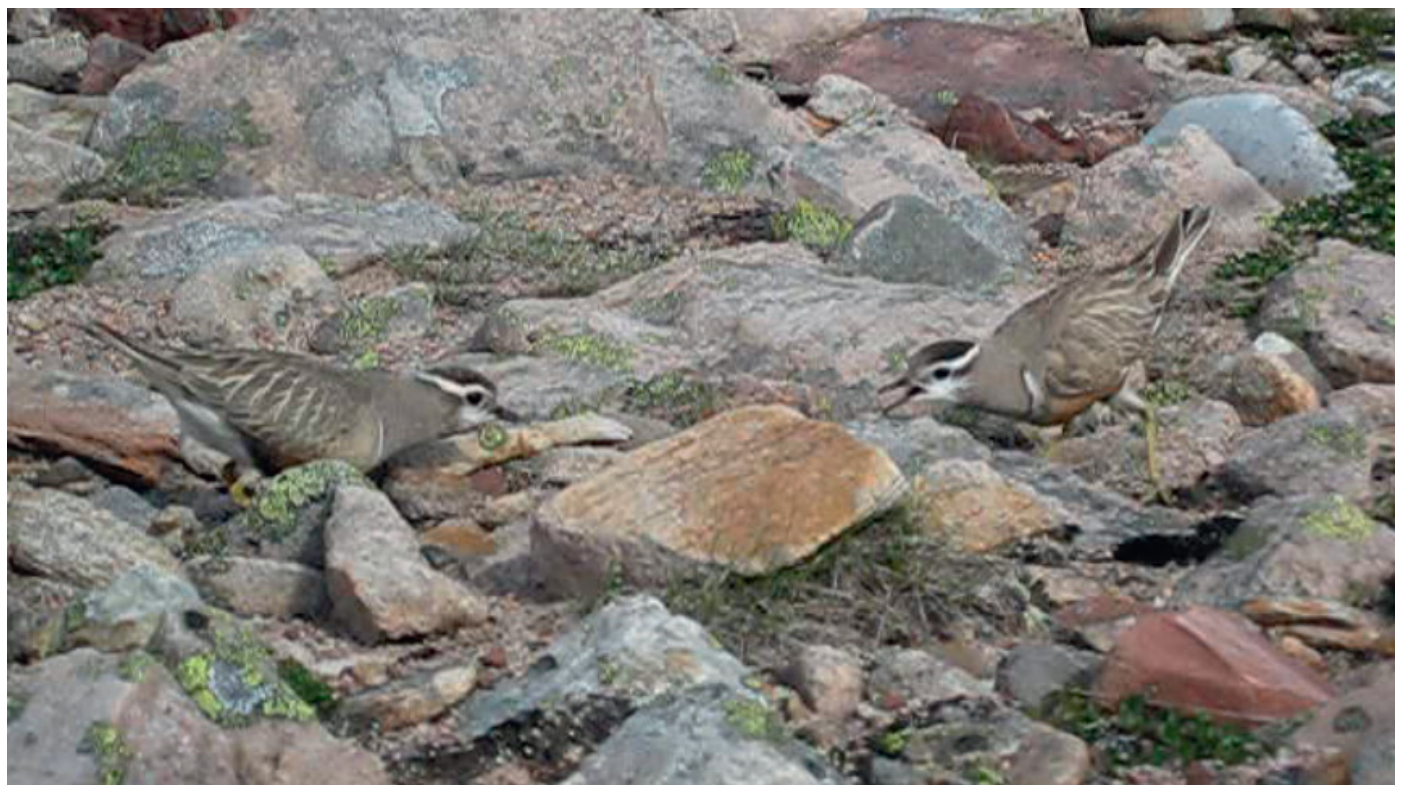

Figure 3. A female Dotterel (right) drives away its mate to prevent him from inculating the chicks.

En fjällpilparhona (höger) driver bort sin make för att hindra honom från att värma ungarna. 


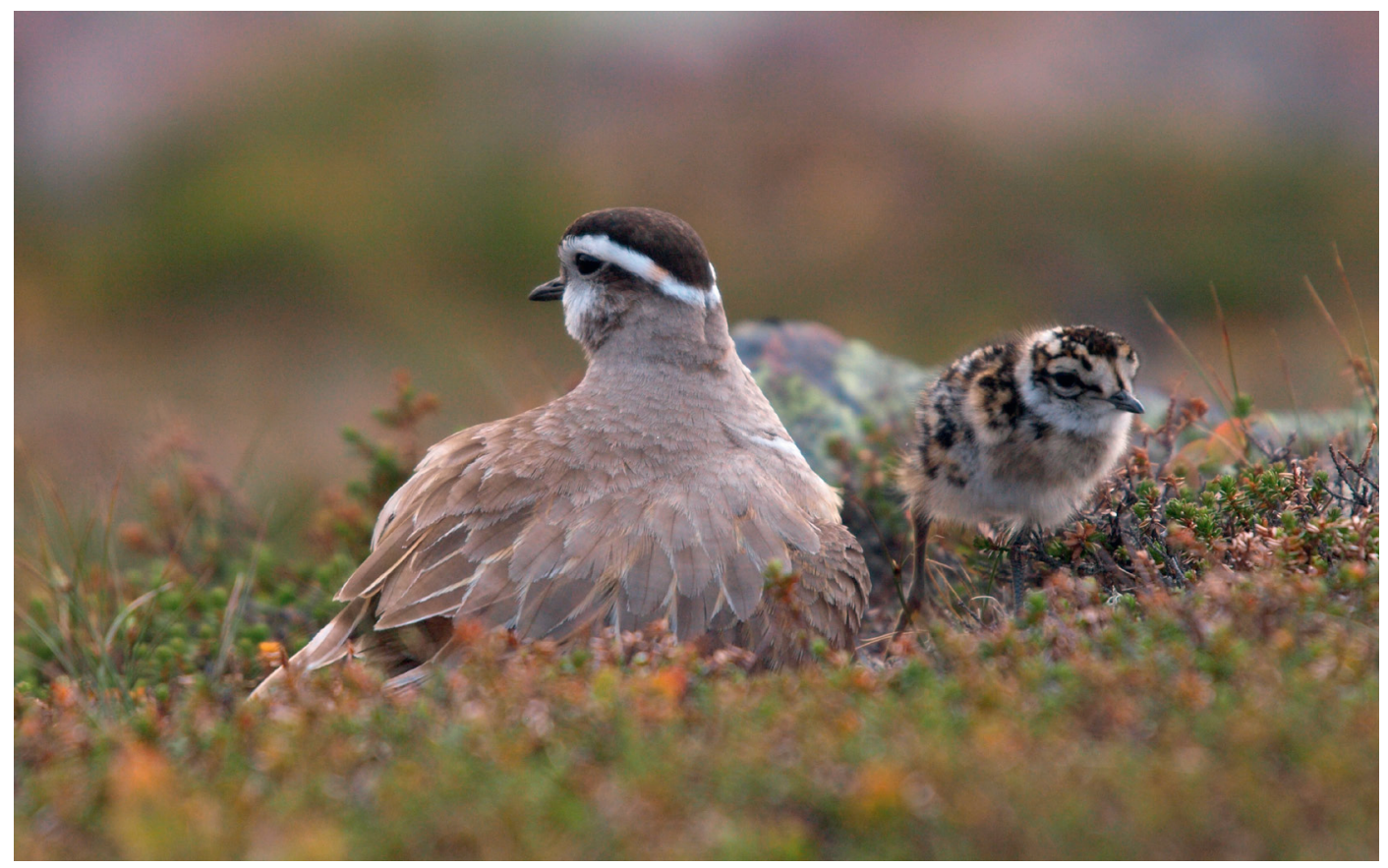

Figure 4. A female Dotterel with one of three chicks that were several days old. En fjällpiparhona med en av tre ungar som var flera dagar gamla.

times over for $3 \frac{1}{2}$ hours; the female won each time. We stopped observing at $16 \mathrm{~h} 40 \mathrm{~m}$ because temperature dropped sharply and the chicks remained under the female to stay warm. The next morning we found the male at $10 \mathrm{~h} 55 \mathrm{~m}$, still brooding the chicks in the nest, nearly 24 hours after the last chick had hatched; but we failed to find the female.

Over the years and always after 4 July we came across 8 families from unknown nests (Table 1); in 7 cases the chicks were being led by an adult male. But on 18 July 2009, we found two adult birds leading 3 chicks each, about $400 \mathrm{~m}$ from each other. One male, not far from a nest that had hatched a few days earlier, and a female (Figure 4)! The birds were in a small area, situated between the new Batsfjord road, the parallel old road, a creek and an impenetrable area with boulders that were too big for small chicks. The female stayed there for 5 days, the male for a week. We never observed them coming close to each other. The chicks were about the same size.

In 2004 we spotted a clutch in the very same depression where we had found one in the previous year, a phenomenon that to our knowledge is quite rare in any Charadriidae species! In 2009, a nest was found only about 20 metres from one used in 2008. But since we had no permit for colour banding, it was not possible to prove that the incubating birds were the same as in 2008. So we only have one case that proves that site fidelity does exist.

From 2004 to 2010 we found 3 loose "neighbourhoods", that is pairs of nests which were less than $100 \mathrm{~m}$ apart. In 2008 both nests were incubated by different females and males, which means that close vicinity is not necessarily a consequence of serial polyandry (one female laying several clutches for at least two males). By photographing the birds we were able to prove that there were two different males and two females. On three occasions the male of nest 1 approached the breeding male on nest 2 until the latter chased him away. In 2010 we found a cluster of three nests in an area of less than 15 hectares. But in spite of great efforts, we were unable to find any other nests nearby in similar optimum habitat.

When Dotterel approach the nest to relieve their 


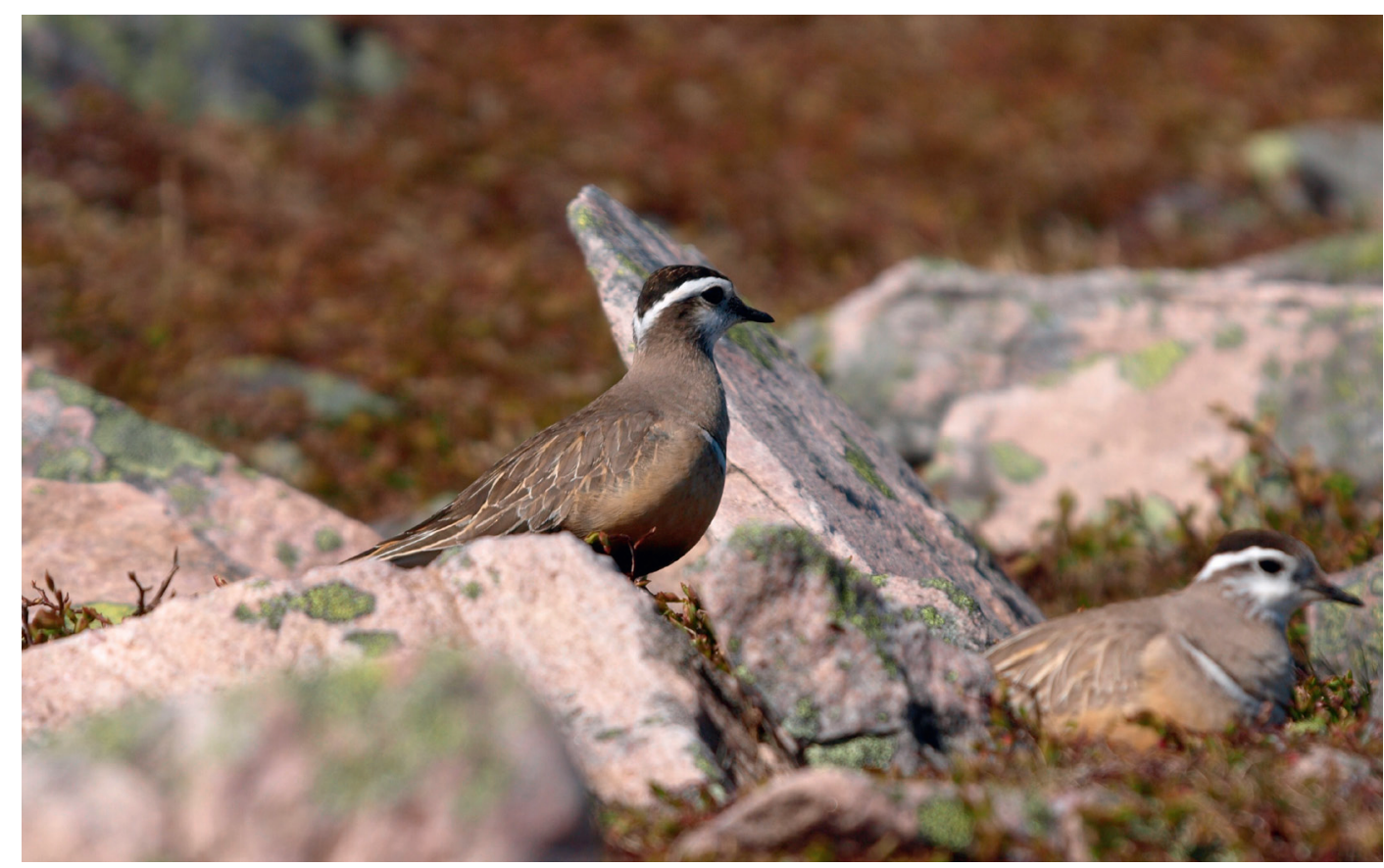

Figure 5. Normally the incubating Dotterel leaves the nest well in advance when its mate arrives to take over attendance of the nest. Here a rare case when both birds were observed together less than one meter apart. The male to the left.

Normalt lämnar den fjällpipare som ruvar boet $i$ god tid innan maken anländer för att ta över. Här ett sällsynt fall där båda fåglarna observerades mindre än en meter från varandra. Hanen till vänster.

incubating partner, the latter normally leaves the clutch well before the other bird arrives. Only once we managed to see (and photograph) both birds less than $1 \mathrm{~m}$ apart (Figure 5).

\section{Discussion}

Although our sample ( $\mathrm{n}=24$ nests) is rather small, a percentage of at least $75 \%$ of shared incubation seems to show that this practice may be more frequent at the northern fringe of this species' breeding range than in subarctic and southern Fennoscandia. L. Saari (Pulliainen \& Saari 1996 and L. Saari written comm.) suggests that most females on Värriötunturi ( $\left.67^{\circ} 41^{\prime}\right)$ in Finland leave the area in mid-June after egg-laying, perhaps in order to look for more males further up north. It is a fact that they can lay up to 5 clutches (Holt et al. 2002), so if the sex ratio in one area is sufficient to allow all males to have a clutch, why not go elsewhere to maximize reproductive success? Such a female's last male partner may have better survival chances in the harsh climate of the high arctic if shared incubation allows him to feed more often and for much longer periods. The hypothesis of females covering large distances between two clutches might one day be studied using telemetry and colour-banding. But catching an egg-laying female is not easy and it may even make the bird leave the nest and jeopardize the success of the clutch. It may be ethically defendable though to catch one of the incubating females during the last days before hatching. At this stage it seems least likely that both birds abandon the clutch in a case of major disturbance. However, the probability of a satellitetagged bird flying back to an accessible part of the Arctic where its behaviour and partner(s) can be studied further in the following year seems weak if the hypothesis of low site fidelity is correct.

To our knowledge female Dotterel that successfully defend their hatching chicks against their partners have never been reported before. We do not have an explanation for this behaviour; the male bird had only been identified once on the nest before hatching. Since we only found one single case, more research during hatching periods would 
be necessary to assess if this pattern is more frequent, and how it can be explained.

One of the major difficulties of our work was the simple fact that Dotterel are so elusive. The only areas with a greater chance to find nests were near the reindeer fences parallel to road 891, as well as along two dirt roads. 10 of our 25 nests were less than 50 metres from one of these conspicuous lines, among which there were 6 nests that were no more than 25 metres away. It may be easier for the bird to locate its nest if there is some prominent land mark in an otherwise featureless landscape.

The question that concerns the very shy birds we happened to find is: are these individuals exceptions or more frequent than we think? Perhaps the majority of nests we found belonged to confiding birds which might not be as common as we believe; the real number of breeding birds in a given area may be much higher than the few nests we managed to find. And why do some pairs breed in close vicinity when no other nests can be found anywhere else in the same habitat? We think that Dotterel densities are underestimated in vast areas like the Varanger plateaus. Ringed Plovers and Golden Plovers may only seem to be more numerous because they are easy to spot. Dotterel are altogether far less visible than all other fell breeding wader species. To assess the true density of this species in this type of habitat, larger teams of searchers would be needed.

As for the unlikely but in our view not impossible occurrence of double-clutching, our observation of a lone female with several day-old chicks remains at least very odd. As far as we know this behaviour has not been previously reported. It is true that Kalas (1986) had once removed a breeding male from a nest and showed that the female managed to take care of eggs and chicks. Predation of "our" female's partner is not unthinkable but we believe that this risk is unlikely, as the number of potential predators that could catch an adult Dotterel in good health seems extremely low in this area. We have indeed never witnessed an attack on adult Dotterel in more than 200 days of monitoring and were once surprised at how relaxed a brooding bird remained in spite of a gyrfalcon and an attacking skua that flew over its nest at high speed. Since Dotterel on Varangerfjell breed during the midsummer night sun period on flat, open terrain, no predator can approach their nests unseen. As the chicks accompanied by the neighbouring male were about the same size, a case of double-clutching between these two birds seemed to be unlikely. But there may have been a second male there, with whom the female might have paired up. Among the hundreds of Dot- terel pairs that have been watched by scientists so far, no other chick-leading females have ever been recorded to our knowledge. But does this mean that double-clutching in Dotterel can be totally ruled out? If not, it must be a rare phenomenon but we do not think it is impossible. If there was evidence that Dotterel sometimes or systematically use this strategy near the birds' northernmost frontier in the Arctic region, this would probably mean that they thus try to boost their breeding success as much as possible.

Since an unknown proportion of Dotterel pair up in their winter quarters and therefore may breed thousands of kilometres from last year's site (Géroudet 1982, Cramp \& Simmons 1983), we were not surprised to find little evidence of site fidelity. The frequency of this phenomenon could also be explored by further research. By satellite tagging birds in their winter quarters it might also be possible to find out if it is the males that pair up before or during spring migration and take their partners to the nesting site or if the latter decide where they will breed.

\section{Acknowledgements}

I am very grateful to the Norwegian Red Cross, Ms Inger Klausen, Ms Lilly Wahl and the Bremnes family from Batsfjord for helping me with accommodation. I am particularly grateful to Ted Green, David Hartridge, Alex Parker and Mike Bowman for valuable comments on an earlier draft of the manuscript and proofreading. I also thank Matti Koivula and Lennart Saari for their insightful suggestions on this article as well as Bo Fagerström and Lennart Saari for the Swedish and Finnish versions of the abstract.

\section{Postscript added in August 2011: Additional observations made in $\mathbf{2 0 1 1}$}

We (L.L., B.K. and J.-M. Lustrat) studied the birds in our two areas from 22 June to 31 July 2011. All our findings confirm our hypotheses made since 2002.

We found 9 nests, two of which might have belonged to the same pair. One very late clutch (completed on 9 July) was abandoned, most of the other nests must have been robbed by Arctic Skuas after a lemming peak crash. Only two clutches, perhaps three, hatched for sure. Five clutches were checked for at least five days. Four (80\%) were found with females that incubated at least one day well after egg-laying. One female incubated at least from 5 
to 27 July, before the second chick hatched. This is the fourth time we found a female Dotterel with at least one chick. (Video on http://www.youtube. $\mathrm{com} /$ watch? $\mathrm{v}=$ CKAQLKhhdi4).

We found at least 11 other families, only 2 or 3 of which might have been counted twice or belonged to a known nest. On 31 July we found 5 different families in an area of less than 50 hectares within 1 hour and 40 minutes, which seems to prove that Dotterel on Varangerhalvöya are actually quite common. They are just extremely difficult to detect when incubating (which corresponds to the period when most birdwatchers try to find them, thus believing that they are much less common than other Plovers). Again, four of the 9 nests were less than 20 metres away from man-made structures (fence, road, track or ditch).

The most surprising occurrence this year: the very same nest scrape that had been used in 2003 (male) and 2004 (male and female) was used again this year (by male and female). To our knowledge such a phenomenon has never been found in any Charadriidae species. (Photo proof on https://picasaweb.google.com/117170977024927019906/ Lapland2011\#5628159771688284242

This sheds new light on the supposedly "weak" site fidelity of this species. One may speculate that the males tend to be extremely faithful to their once chosen breeding place whereas females may pair up in their winter quarters, and then, after laying a first clutch, wander across large parts of Fennoscandia and Russia. This would explain the birds (of unknown sex) that were ringed in Europe and found or killed in central or eastern Siberia (Hable 1975, Géroudet 1982). About $80 \mathrm{~m}$ from this nest scoop, there was another clutch, only a few metres away from nests discovered in 2004 and 2006.

\section{References}

Aarvak T. \& Øien, I.J. 2009. Monitoring of Bean Goose in Finnmark County, Norway - results from 2008. Norsk Ornitologisk Forening. NOF rapport 2-2009, 10 pp.

Arendt, E., Schweiger, H. 2007. Tiere vor der Kamera: Die Saga vom Vogel in der Hand. No. 42, DVD, 43 min., Bayerischer Rundfunk, ERA-Film-Produktion.

Berg, B. 1917. Min vän fjällpiparen. Norstedt, Stockholm, $157 \mathrm{pp}$

BirdLife International. 2009. Eudromias morinellus. In: IUCN 2010. IUCN Red List of Threatened Species. Version 2010.4. <www.iucnredlist.org>

Cramp, S. \& Simmons, K.E.L. eds. 1983. Handbook of the Birds of Europe, the Middle East and North Africa. The Birds of the Western Palearctic. Volume 3, Waders to Gulls, Oxford: Oxford University Press.

Géroudet, P. 1982. Limicoles, gangas et pigeons d'Europe.
Vol. 1. Delachaux et Niestlé

Hable, E. 1975. Eudromias morinellus (Linné 1758) - Mornell. In: Glutz von Blotzheim, U., Bauer, K. \& Bezzel, E., Handbuch der Vögel Mitteleuropas Vol. 6: 281-315. Akad. Verlagsges. Wiesbaden.

Holt, S., Whitfield, D.P. \& Gordon, J. 2002. Potential reproductive rates in the Eurasian Dotterel Charadrius morinellus. Bird Study 49: 87-88.

Kalas, J.A. 1986. Incubation schedules in different parental care systems in the Dotterel, Charadrius morinellus. Ardea 74: 185-190.

Kalas, J.A., Byrkjedal, I. 1984. Breeding Chronology and Mating System of the Eurasian Dotterel (Charadrius morinellus). The Auk 101: 838-847.

Kausrud, K.L., Mysterud, Steen, A.H., Vik, J.O., Cazelles, B., Framstad, E., Eikeset, A.M., Mysterud, I., Solhøy, T. \& Stenseth, N.C. 2008. Linking climate change to lemming cycles. Nature 456: 93-98

Kraatz, S. \& Kraatz, B. 2004. Beobachtungen an einer Brut des Mornellregenpfeifers Charadrius morinellus. Limicola 18: 1-15.

Kraatz, S. \& Kraatz, B. 2006. Beobachtungen zur Brutbeteiligung des Weibchens beim Mornellregenpfeifer Charadrius morinellus. Limicola 20: 91-98.

Maynard Smith, J. 1978. The Evolution of Sex. Cambridge University Press, Cambridge.

Nethersole-Thompson, D. 1973. The Dotterel. Collins, London.

Owens, I.P.F., Dixon, A., Burke, T. \& Thompson, D.B.A. 1995. Strategic paternity in the sex-role reversed Eurasian Dotterel (Charadrius morinellus): Behavioral and genetic evidence. Behav. Ecol. 6: 14-21.

Piersma, T. \& Wiersma, P. 1996. Scolopacidae. In: Handbook of the birds of the world. Vol. 3. Hoatzin to auks. Edité par Josep del Hoyo, Andrew Elliot et Jordi Sargatal. Lynx Editions, Barcelona.

Pulliainen, E. 1970. On the breeding biology of the Dotterel Charadrius morinellus. Ornis Fennica 47: 69-73.

Pulliainen, E., Saari, L. \& Tunkkari, P. 1992. Keräkurmitsa - Värriötunturin lintu (The Dotterel, a bird of the Värriötunturi fell. English abstract). Oulun yliopisto, $40 \mathrm{pp}$

Pulliainen, E. \& Saari, L. 1994. Incubation behaviour of the Dotterel Charadrius morinellus in Finland. Oecologia Montana 3: 27-34.

Pulliainen, E. \& Saari, L. 1996. Pre- and non-breeding biology of Dotterel Charadrius morinellus in Värriötunturi fell area, NE Finland. Wader Study Group Bull. 81: 54-58.

Pulliainen, E. \& Saari, L. 1997. Attendance at the nest of polyandrous Dotterel Charadrius morinellus in Finland. Ardea 85: 67-71.

Rassi, P., Hyvärinen, E., Juslén, A. \& Mannerkoski, I. (eds.). 2010. The 2010 Red List of Finnish Species. Ministry of the Environment and Finnish Environment Institute, 685 pp.

Saari, L. 1995. Population trends of the Dotterel Charadrius morinellus in Finland during the past 150 years. Ornis Fennica 72: 29-36.

Wetlands International. 2002. Waterbird Population Estimates. Wetlands International Global Series No. 12. Wageningen, The Netherlands. 


\section{Sammanfattning}

Fjällpiparen är polyandrisk och det är känt sedan länge att honorna ofta lämnar äggen och partnern efter läggningen för att söka upp en ny hane och lägga nya ägg. Ett löst förhållande till den första hanen kan dock bestå, exempelvis att varna för faror. Att honor i viss utsträckning kan delta i ruvningen är känt. Däremot har man aldrig observerat honor som tagit hand om ungar. Ortstroheten anses vara svag. De huvudfrågor vi studerade var om honorna deltog i ruvningen och hur länge de i så fall ruvade. Andra saker vi studerade var om det fanns honor som tog hand om ungar efter kläckningen, om det förekom att en hona och en hane ruvade varsin kull (förkommer hos en del vadare), om alla fjällpipare hade samma tillitsfulla beteende vid boet samt om det fanns tecken på ortstrohet mellan åren.

Åren 2002-2010 följde vi 24 fjällpiparbon i Varangerfjällen nära Båtsfjord i norra Norge (Tabell 1). Vi fann att honorna med säkerhet deltog i ruvningen i minst arton fall, och deras deltagande kunde inte uteslutas i de övriga sex fallen. Figur 2 visar det troligen första fotot av en hona som ruvar under kläckningen. En hona försvarade sina ungar mot sin partner innan ungarna lämnat boet. En annan ensam hona sågs leda tre ungar under fem dagar inom ett mycket litet område. Detta är enligt vad vi vet det första fall som någonsin observerats av en hona med ungar utanför boet. Könsbestämningen hade vi inga problem med vid gott ljus. I detta område hade de ruvande honorna mycket ljusa kinder med få eller inga mörka streck, bakre delen av hjässan var svartaktig med få eller inga bruna streck och honans buk hade klart mera svart än hanens (Figur 1).

Vi fann att alla fjällpipare inte var så orädda som man oftast upplever dem. Vid tre bon var fåglarna så varska att de flög iväg redan på 80 till 300 meters håll, vilket innebar att vi inte kunde eller hade svårt att könsbestämma den ruvande fågeln. I ett fall trodde vi till och med att boet var övergivet, men då fann vi ändå en orädd ruvande hona på två nykläckta ungar och ett ägg. När det tredje ägget höll på att kläckas anlände hanen och försökte lägga sig och värma den först kläckte ungen som sökte föda fyra meter från boet. Men honan jagade aggressivt iväg honom (Figur 3 och Appendix). Nästa dag fann vi hanen värma ungarna i boet men kunde inte finna honan. Det normala vid ruvningsbyte var att den ruvande fågeln lämnade boet $\mathrm{i}$ god tid innan den andra fågeln anlände. Bara en gång såg vi båda fåglarna mindre än en meter från varandra (Figur 5).

Det faktum att en del fjällpipare är skygga och lämnar boet långt i förväg när en observatör närmar sig kan innebära att inventeringar som baserar sig på bofynd eller bobeteende underskattar beståndstätheterna. Det kan vara så att det mestadels bara är de oskygga fåglarna som man registrerar. I vårt studieområde bedömde vi att tätheten var ungefär tio par per kvadratkilometer, vilket indikerar att fjällpiparen är rätt vanlig på Varangerhalvön.

Under årens gång, och alltid efter 4 juli, fann vi sammanlagt åtta familjer från för oss okända boplatser (Tabell 1). I sju fall var det en hane som hade hand om ungarna. Men vid ett tillfälle kom vi på två gamla fåglar som ledde vardera tre ungar ungefär 400 meter från varandra. Den ene var en hane, inte långt från ett bo som hade kläckts ett fåtal dagar tidigare, och den andra en hona (Figur 4). Honan vistades på platsen under fem dagar och hanen en vecka. Vi såg dem aldrig vistas riktigt nära varandra. Ungarna var av samma storlek. Detta var det närmaste vi kom en möjlig indikation på att en hona kan ha lagt en kull åt hanen och en annan åt sig själv inom ett begränsat område.

Flera bon hittades mindre än 100 meter från varandra och en hona lade ägg i samma bogrop två år i rad. Dessa observationer kan tyda på ortstrohet, men eftersom vi inte hade några märkta fåglar kan vi inte avgöra om det vara samma eller nya fåglar som återkom till reviren.

\section{Maastohavaintoja keräkurmitsan Charadrius morinellus pesimäbiologiasta arktisessa Norjassa}

Vuosina 2002-2010 seurattiin 24 keräkurmitsan pesää Varankitunturin ylätasangolla Båtsfjordin lähistöllä Pohjois-Norjassa. Naaras osallistui haudontaan vähintään 18 tapauksessa, eikä naaraan osallistumista voitu poissulkea lopuissa kuudessakaan. Eräs naaraista puolusti poikasiaan puolisoaan vastaan sekä kuoriutumisen aikana että sen jälkeen. Toinen yksinäinen naaras nähtiin johdattavan kolme poikastaan viiden päivän aikana hyvin suppealla alueella tutkimusalueen sisällä. Useita pesiä löytyi alle 100 metrin etäisyydellä toisistaan. Eräs naaraista muni samaan pesäkuoppaan kahtena peräkkäisenä vuotena. Muutamat näistä havainnoista täydentävät aiemmin julkaistuja havaintoja ja tukevat aiemmin esitettyjä hypoteesejä keräkurmitsan pesinnästä.

\section{Appendix}

A rare video document: a male and a female fighting for parental care of the chicks. http://www.vimeo.com/7435068 